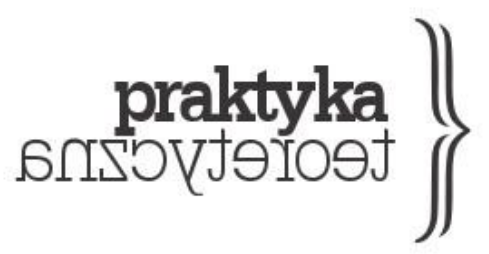

\title{
WAS It A STRIKE? Notes ON THE POLISH WOMEN's STRIKE AND THE StRIKe OF PARENTS OF PERSONS WITH DISABILITIES
}

\author{
JULIA KUBISA, KATARZYNA RAKOWSKA
}

\begin{abstract}
Two significant social protests that took place in Poland in recent years - a massive mobilisation of women against a ban on abortion and an occupation of the Sejm building by carers of persons with disabilities - were called strikes. In this article, we analyse the Polish Women's Strike events of 2016, 2017 and 2018 and the strike of parents of persons with disabilities of 2018 from the perspective of a strike as a form of protest. What does it mean that both protests have been called strikes and what are the implications of incorporating the terminology of labour disputes by both protests? Strikes in Poland are a form of collective, institutionalized industrial action of workers in wage employment, organized only by a trade union registered in a certain workplace and its subject can be exclusively of workplace matters and not on matters that are political and beyond an employer's influence. The Polish Women's Strike and the protest of parents of persons with disabilities were not strikes de iure, however they rejected division between production (wage labour) and reproduction (non-wage labour), which gave a deeper meaning to the "refusal of work". The empowerment of this event was derived from taking over the concept of the strike and providing an inclusive space to connect different actions related to struggles for reproductive rights. We interpret this as a strategy of cooptation and occupation of typical protest actions reserved for wage labour.
\end{abstract}

Keywords: strike, protest, Women's Strike, Black Protest, Parents of Disabled Persons, reproductive labour, care work 


\section{Introduction}

In recent years, two social movements that gathered political and social recognition in Poland used a term that was long associated with industrial relations. The massive protests against a planned ban on abortion in 2016, 2017 and 2018 named the Polish Women's Strike, and a protest occupation of the Sejm, the lower chamber of the Polish Parliament, by the people with disabilities and their carers, which was called "a strike" in the media debate are two important social phenomena that are linked in a multidimensional way. In both cases care and reproductive labour were brought to the front, as the major point of their political agenda. And in both cases their actions were framed as "a strike".

We analyse the Polish Women's Strike events of 2016, 2017 and 2018 and the protest of parents of persons with disabilities of 2018 from the perspective of the strike as a form of protest. We are interested in the meaning of the fact that both protests have been called strikes and in the theoretical and political implications of cooptation the terminology of labour disputes by both protests. In order to meet the aim of the article, we analyse both protests through the lens of the strike as an industrial action framework: in terms of the goals of a strike, the form and basis of mobilisation, the methods of action, the main actors, time and place, the institutional aspect, the agenda and demands, the major adversaries and the character of work. We apply the industrial relations framework of strike elements in order to analyse the potential consequences of the free use of terminology from one domain in another domain, both for social movements and for industrial relations discourse.

Formally, strikes in Poland are a form of collective, institutionalized industrial action of workers in wage employment. A strike can be organized only by a trade union registered in a certain workplace and its subject can be exclusively of workplace matters. Trade unions as strike organizer need to fulfill a detailed procedure and cannot strike on matters that are political and beyond the employer's influence. This article looks for a scientific elaboration on a social situation when a very specific term is used in a new context. In order to analyse this social phenomenon we use a triangulative approach, combining an industrial relations perspective with a special focus on the institution of the strike, a feminist perspective on gendered division of labour, and with a special attention to care work and reproductive labour. The concept of "politisation of care", coined by Linda Briskin (2013), is a proxy that enables this multifaceted framework.

The structure of the article is as follows: first we discuss the theoretical framework, then we present brief characteristics of two social protests and the research so far on the two protests. This allows us to situate our research questions. Next, we present the methodology and analytical tools, and the results and discussion that leads to answering the research questions. 


\section{Theoretical framework}

The usual axis of the abortion debate in Poland is focused on moral issues reflected in the "pro-choice" / pro-life (anti-choice)" opposition, with Catholic church as the disposer of one morality and the feminist movement as the other one (Graff 2001, Szczuka 2004). The debate on care for people with disabilities is often framed into a discourse of "motherhood sacrifice" that can be characterised as moral and emotional (see Hołub 2018). However, the term "strike" used in the case of both social protests enables us to seek a more material interpretation.

For our theoretical background we use the Polish framework of industrial action with special attention to the sociological concept of the strike and concepts of productive and reproductive work, and the politisation of care work.

A strike action is strictly regulated by Polish law as the ultimate step of industrial conflict (Ustawa 1991). A strike can be performed only by wage workers against an employer. It can be organized only by a trade union recognized in certain workplace. The subject of a strike can be exclusively of workplace matters like wage and working conditions. Strikes in Poland cannot be performed in order to change national government politics or law. Therefore, it is forbidden to strike for a higher minimum wage and political strikes are forbidden. Also a general strike is not allowed in Poland. Trade unions as strike organizers need to fulfill a detailed procedure before attempting to strike and it should be treated as an extreme action in the case when all others means of resolving industrial conflict failed. This procedure involves organizing, filing demands, parley, mediations and a strike referendum with a turnout of $50 \%$ of the workers, of whom at least $50 \%$ vote for the strike.

It is worth mentioning that according to Polish law not every group of workers has the right to strike. Many groups are excluded from the right to strike by their occupation, like policemen, firefighters, soldiers, customs officers and other public officers. Others do not have the right to strike due to their employment status. A collective bargaining process can be undertaken only by those employed under an employment contract that is regulated by the labour code, leaving behind many workers employed on the basis of civil contracts.

In the sociology of work, a strike is defined as "the collective withdrawal from work of a group of employees to exert pressure on the employer over any issue in which the two sides have a difference" (Watson 1995, 386). Hyman uses the classic definition of a strike presented by Griffin, for whom a strike is "a temporary stoppage of work by a group of employees in order to express a grievance or enforce a demand" (Hyman 1990, 17). Burns focuses on the practical aspects of a strike and emphasises its economical aspect. The biggest power of a strike is therefore stopping production, not only by withdrawing from work but also by sit-downs and blockades. Burns also brings attention to collective aspect of an industrial strike, underlying the importance of the solidarity of workers (Burns 2011). Brecher, on the other hand, sees a 
broader class conflict, where the issue is not a struggle for power between two sides employees and employers. "The real issue is an attempt by workers to wrest at least a part of the power over their lives away from their employers and exercise it themselves" (Brecher 2014, 297). In this concept, a strike has two important aspects: a tendency toward self-management and towards solidarity - powers that could transform society. That is why Brecher does not distinguish between political and economic struggles, stating that a strike has both qualities. In Polish sociology of work, Masewicz constructed a more operational definition of a strike, as an act of collective action of employees inspired and guided by a trade union or ad hoc determined representation (strike committee) that aims to change or preserve the status quo of workers' rights and occupational interests (Masewicz 1986). The most complex definition, focusing on the constitutive aspects of strike was presented by Kałuszka and Szymański, who define a strike as a class occurrence of the proletariat that consists of pressure towards employers or the state in the form of total or partial withdrawal from work or other forms of disturbance of the production process, in order to cause losses for an employer or to manifest a standpoint towards state authorities (Kałuszka, Szymański 1982). A similar definition is given in the Sociology of Work Encyclopedia (Smith, 2013), which describe a strike as "coordinated cessations of labour to maximize pressure on employers during labour disputes, are one of the main forms of worker collective action. Strikes vary considerably in terms of duration, scope, and participation. Some aim at obtaining better wages, benefits, and working conditions; others attempt to prevent cuts in these and still others are motivated by political objectives. [...] Strikes are usually called by unions when negotiations fail to satisfy employee demands." Based on the latter two definitions, we propose to look at strike actions with the use of certain categories that can distinguish a strike action from other forms of protest.

The literature distinguishes between several categories of strikes in relation to different aspects of activity. Considering the scope of a strike it can be local, performed in one workplace, a branch strike and a mass or general strike that includes most or a great number of workers from different workplaces and branches. In relation to the aims of the strike, there are offensive or revindicative strikes that aim to acquire new rights or benefits, and defensive strikes that want to maintain the status quo. In relation to methods researchers distinguish between traditional strikes when employees stop working and leave the workplace and sit-in strikes that involve occupation of the workplace. For the purpose of our research we want to mention also solidarity strikes, which aim to support other striking workers or the demands of those who cannot strike (Kałuszka, Szymański 1982, Masewicz 1986).

The sociology of work focuses also on other forms of labour protests apart from strike. In our analysis we use the concepts of blockade, occupation, picket and demonstration as other forms of protests accompanying strikes or performed instead of a strike. Those forms of protest in the Polish context were characterised by Jarosław Witkowski (2012). Occupation is 
a protest during which protesters take into possession workplace buildings and its appliances, thus disturbing normal production activity. A blockade, on the other hand, is an action that forecloses the usage of public buildings, roads, passages, tracks and other communication routes, and blocks or makes harder to enter certain buildings or locations. A picket usually takes the form of displaying posters, handing out leaflets, especially during rallies (Witkowski 2012). The word demonstration is used for rallies bigger than pickets, especially those including marching (Dialog 2019).

The second dimension of our theoretical framework is built on the concepts of productive and reproductive labour, the public patriarchy and the politicization of care work. In order to grasp the meaning of the social movements' agenda we turn to the feminist theories that elaborate on the concept of reproductive labour and the specifics of care work. Women's unpaid work at home became a vital subject for feminists in the 1970s analysed with sociological and economic tools and inspired by Karl Marx' and Friedrich Engels' discussion on the reproduction of labour, necessary to the maintenance of that productive economy. Various feminist scholars argued that reproductive labour should be socially recognized as indispensable to the maintenance of a productive labour force and society (Dalla Costa 1972; Hartmann 1976; Secombe 1974; Duffy 2007). This brought further debates on the gendered division of labour, because of which women are constantly denied equal status on the labour market due to the invisible burden of reproductive labour performed at home. The term "reproductive labour" can be understood as work that maintains daily life (physical or mental health, food preparation and service, cleaning, personal care) or work that reproduces the next generation (care of children and youth) (see Nakano Glenn 1992; Duffy 2007). One of the most prominent voices in the debate, Silvia Federici (1975), applied a productive labour framework to the conditions of housework. In her view, what is called love is actually unwaged work; what is called frigidity is absenteeism; and each miscarriage is a work accident. She called neurosis, suicides and desexualisation occupational diseases.

Reproductive labour is not, however, a sort of a private relation between a working husband and housewife. It is a domain of structural exploitation. In the view of Silvia Federici and other marxists feminists, women who perform reproductive labour are directly exploited by capital the way workers are exploited (see Tong 2002). One of the ways of obscuring the exploitative character of the activity that is socially and economically indispensable is its devaluation. Nancy Fraser adds that work for social reproduction comprises both affective and material labour and points out that "capitalist societies separate social reproduction from economic production, associating the first with women, and obscuring its importance and value" (Fraser 2016, 102). Sylvia Walby's work on gender regime helps us understand the transfer from private to public patriarchy, present in six interrelated structures: paid work, household production, culture, sexuality, violence and the state (Walby 1990, 1997). Therefore 
the reproductive labour and its value should be seen as part of a socio-economic system, regulated and controlled by the gendered state. In the ongoing gender regimes, care and care work are still considered as some kind of natural vocation and ability of women, who perform it as a form of "labour of love". When care becomes a profession, it is undervalued in terms of wages and working conditions. Yet, at the same time, the social needs for care and care work are increasing - due to the ageing of society, higher participation of women in the labour market, and the change of gender roles and relations. The tensions between the social needs and the ongoing undervaluation of care and care work are clearly observed. This enables a reformulation of the reproductive labour and care work into the domain of struggle. Linda Briskin (2013) draws attention to the strike activity of nurses - an occupational group that performs care as a profession, referring to it as "politicization of caring": a recognition of the collective responsibility for caring, and the impact of deteriorating conditions of nursing work on quality care; the rejection of essentialist claims that women are responsible for caring work by virtue of being women; the demand that the skills involved in caring work be recognised and rewarded; and the willingness to mobilise collectively to these ends'. (Briskin 2013, 120). Silvia Federici (2008) discusses the possibilities of setting a fight against reproductive labour, but not the people who are part of the care relation. She calls for a distinction between the creation of human beings and the reproduction of them as future workers in a form of labourpower. Thus the struggle in reproductive labour is not against people who are cared for, but against the systemic processes and mechanisms of oppression that take away the control over reproduction and care from their performers. Therefore, our framework does not only include the concept of reproductive labour but also the potential of labour-based protest in the domain that is usually privatised and treated as a natural duty and calling. The feminist framework of reproductive and care work consists of the recognition of social reproduction and care as work, the exploitation of persons performing this work in a gendered state and capitalist relations, and the potential for struggle against the oppression in order to define and perform reproduction and care work on their terms.

\section{Two strikes: the Polish Women's Strike and the Protest of Parents of Persons with Disabilities}

In order to understand the phenomenon of both protests in the strike perspective, we now move to the contextual description of the events and processes that took place before the actual 'strikes' happened. Both protests have grown on the ground of longstanding social struggles. In order to understand the Polish Women's Strike, it is important to point out that the political actions against the severe anti-abortion law date back to the early 1990s, when access to abortion was institutionally denied by Polish Parliament with three exceptions (Mrozek 2018). 
The subsequent years brought the development of the so called "abortion underground" (Kacpura et al 2016) and, interestingly, a drop in the fertility rate (GUS 2016). In political terms, the severe law shaped new divisions: it triggered the formation of the feminist movement and, at the same time, political initiatives that aimed at the introduction of a total ban on abortion. However, the political mainstream adopted the "compromise" approach, pointing out that the present legal situation is a balance between different social needs, the so called "protection of life" and basic safety of women (Kacpura et al 2016, Chmielewska et al, 2017). In terms of mobilisation for the purpose of legal change, over past few decades the anti-choice side made several attempts to bring a petition to Parliament that would lead to a total ban on abortion, with the most serious case in 2007 when a group of MPs from the ruling coalition tried to introduce "life protection from conception" to the Polish constitution. All those attempts failed, but it is worth mentioning that each time they were based on a large scale mobilisation of members of the Catholic church. The feminist social movement kept organizing demonstrations, pickets and different forms of social action that would bring abortion to public debate in the context of women's dignity, social and economic safety and freedom of choice. Even though other points of the feminist agenda were mainstreamed (such as care work institutions, discrimination on the labour market, political representation), abortion was still framed as a controversial topic, even though feminist organizations pointed out the massive scale of the "abortion underground" (Kacpura et al 2016, Szczuka 2004).

In 2016, half a year after Law and Justice won Parliamentary and presidential elections, also thanks to the support of anti-choice movements, the Prime Minister announced governmental support for the idea of a total ban on abortion. At the same time an extremely conservative organization Ordo Iuris started collecting signatures in support of prison sentences for women undergoing abortion procedures and gynaecologists performing them, and a criminal investigation procedure that would check if miscarriage was or was not induced by medical abortifacients. Those two events triggered social discontent: demonstrations and pickets organized by newly formed Gals for Gals (Dziewuchy Dziewuchom), a grassroot movement; and the start of a legislative initiative Save the Women for the liberalisation of the anti-abortion law, organized by a group of social democratic feminists.

In mid-2016 both petitions, Save the Women and Ordo Iuris, were submitted to Parliament. The feminist initiative was immediately rejected, while the OI petition proceeded to further discussions. This provoked demonstrations by Save the Women, and by the left-wing party Razem, which called on supporters to dress in black and join pickets or to post photos in social media, using \#blackprotest (\#czarnyprotest) as the hashtag. Unlike the previous attempts of the extreme conservatives groups, this one was interpreted as a real threat, considering the support expressed by the Prime Minister. When a Polish actress suggested an all-Poland women's strike, inspired by the action of women in Iceland in 1975 who quit work and home 
duties for a day, this idea quickly became viral. During one of the gatherings in Wroclaw, the activist Marta Lempart called for a nationwide women's strike and her call for action is considered the beginning of the Polish Women's Strike (Ogólnopolski Strajk Kobiet - OSK), a nationwide grassroots movement of protest. On 3 October 2016 the Women's Strike gathered thousands. For some towns they were first demonstrations since the strikes of the 1980s during state socialism (Leśniewicz 2016). Women used social media to mobilise and to express their support and demands. The action was very grassroots, organized not by formal women's organizations but a loose network of activists, with the support in the form of resources from the feminist movement and the opposition social movement. The idea of a day of strike gained support from individual employers, the local public administration and faculties at the universities - they were literally telling employees to take a day off on October 3rd or announcing that they will be closed on that day. The participants blocked streets, picketed at the local offices of Law and Justice and joined in massive gatherings on the cities' biggest squares. A couple of days later the government withdrew the support for the OI legislative initiative (Chmielewska et al 2017).

On the 8th of March 2017, the action was repeated as the International Women's Strike in the form of a demonstration in Warsaw and other bigger cities. The winter of 2018 brought another wave of legislative initiatives that aimed at a total ban on abortion. The project was proceeded quickly through the Parliament. This triggered immediate reactions - in less than a week the Gals for Gals and the Polish Women's Strike movement organized massive demonstrations on the 23 rd of March, Friday, breaking a certain "demonstration taboo" that demonstrations should not be organized on working days during traffic hours. Almost 55,000 people marched from the Parliament building to the headquarters of Law and Justice in Warsaw, while in other cities people gathered again on the biggest squares. This time Law and Justice and its government were not the only addressee of the protest - the Catholic Church was directly addressed as well, as one of the major influential political actors (Korolczuk 2018, Kubisa 2018). As an effect of the protests, Law and Justice did not proceed with a project that proposed a ban on abortion.

The struggle of parents of persons with disabilities also lasted several years. In 2014 a group of parents of persons with disabilities and their children were protesting in the Sejm, occupying the building for 17 days. They demanded rising benefits for carers who resigned from wage work to take care of their disabled family members and rising social security allowance to the level of minimum wage. The Parliament raised the benefit but did not match the level demanded. After 17 days of occupation, the group decided to suspend the protest. After four years of further advocacy and negotiations, parents of persons with disabilities decided to renew the protest. The new occupation was initiated and performed by an informal 
group Parents of Disabled Persons (Rodzice Osób Niepełnosprawnych - RON). Part of this group were people who performed the 2014 protest.

On the $18^{\text {th }}$ of April 2018, 18 people, both parents and persons with disabilities, entered the building of the Polish Sejm and started an occupation. They demanded establishing minimum living conditions for persons with disabilities and rising benefits for adult disabled persons. The protest was strenuous: they slept on mattresses on marble floors and did not have access to basic facilities such as a kitchen or tables. Everyday they provided and received care work in public space.The protesters bore both the economical and health costs of the strike. Moreover, the protest faced repercussions from the Parliamentary Guard who used violence (Pacewicz 2018), blocked access to the elevator and bathrooms with a shower (Wprost 2018) which added to additional stress. During the protest, the group got smaller. For some participants the conditions of occupation had too much impact on their physical and psychological wellbeing. Those who left the building for personal reasons were not let back in by the Parliamentary Guard.

The protest of parents of disabled persons was supported by various allies such as informal groups and collectives: The 8th March Women's Coalition (Porozumienie Kobiet 8 Marca, PK8M), the Polish Women's Strike Warsaw (Warszawski Strajk Kobiet), NGO Citizens Solidarity in Action (Obywatele Solidarni w Akcji OSA), trade union Workers' Initiative (Inicjatywa Pracownicza) and a few MPs, like Joanna Scheuring-Wielgus from the liberal Nowoczesna Party who invited the group to the Sejm building and supported the protest on a daily basis.

Everyday the Women on Strike Warsaw with members of other groups, using OSA infrastructure, held an action of support. Food and other necessities were delivered to the occupied building by some Members of Parliament. Supporters of the protest held picketst every day at 16:00 hours in front of the Sejm building. The rally was held in the form of "open microphone". This became quickly a platform of sharing confessions about everyday life experiences of caring for relatives with disabilities. The supporters organized three larger supporting actions. On the 1st of May, during International Workers' Day, collectives of The 8th March Women's Coalition, Women on Strike Warsaw, the Syrena Collective, the trade union Workers' Initiative and the feminist online newspaper Codziennik Feministyczny held a picnic in front of Parliament. The event gathered several hundred participants and offered different kinds of activities like open microphones, drawing postcards to protesters, information stands and even a game of targeting pictures of politicians of the ruling party with fruit, vegetables and eggs. Two demonstrations of support were held during the protest. One of them was held on Polish Mother's Day and used the slogan "Super Mother's Day". Solidarity actions also took place in other Polish cities like Białystok, Gdańsk, Kielce, Kraków, Poznań, Toruń, Wrocław and towns like Grodzisk Mazowiecki, Legnica and Głogów. 
Another form of participation and support for the protest was the activity in social media. Organizers of the strike - Parents of Disabled Persons - posted daily updates from the Parliament. Women on Strike Warsaw announced the public collection of necessities and collected donations every day through social media. Hashtag actions \#supermatki in which women who care for their children with disabilities described their life experiences, and support actions like selfies with slogans of support were shared through Twitter, Facebook and Instagram.

After 40 days of negotiations, the protest ended on the 27th of May 2018, when the 11 remaining people left the building. The demands were not met by the government, who introduced some changes in access to services for disabled people but did not raise benefits. RON is still advocating for their original demands through media and opposition politicians.

\section{Research on the Polish Women's Strike and Parents of Persons with Disabilities protest so far}

The Polish Women's Strike as a social phenomenon was already discussed through various feminist lenses, both in scientific and in more essayistic ways. The first distinguishable theme in the research is focused on the variety of tools for inclusion, with the internet playing a major role in the form of hashtags such as \#czarnyprotest and selfies posted on social media. Majewska (2017) pointed out the change of dynamics between the strong position of the creator and the weak position of the participant, showing the strength of collective creation of the protest by the weak and excluded - the women. Korolczuk (2016) discussed the idea of connectivism, which she described as activism in borderless space that enables emotional engagement, personalisation of political messages and use of information technologies. Kubisa (2017) looked for similarities between feminist demonstrations that are organized in an inclusive way, enabling children and persons with disabilities to take part in the demonstration in a special bus, and the inclusive character of social media actions, calling them "a virtual bus" for those who could not participate in person. Other discussed themes were the role of black outfits as a form of democratisation of the protest (Majewska 2018), the questioning of the private/public sphere division, reproduction and body issues as political issues in the form of an ironic incorporation of discourse. Kubisa pointed out the variety of engagement of different public actors - individual employers being faster in declaring support for the protest than trade unions (Kubisa 2016a). Król and Pustułka (2018) brought the perspective of reproductive justice. They observed that the success of the Polish Women's Strike was rooted in the variety of women who participated - different in their experiences and age, family situation - all united under the broad notion of reproductive justice, identified as access to safe pregnancy 
terminations, sexual education, free access to contraception and sterilization, as well as good prenatal care standards.

The protest of parents of persons with disabilities was mostly commented on in the form of expert analysis. Bakalarczyk (2018) discussed the system of benefits for persons with disabilities and their carers, the possibilities of the realisation of protest demands, the comparison between the protests of 2014 and 2018, and strategies of protest: the engagement of a feminist group and introduction of voices of persons with disabilities. Both protests inspired analogies with the so called first Solidarity movement - Majewska (2018) suggests that the Polish Women's Strike should be seen in this perspective, and Szcześniak (2018b) builds this reference to the protest of parents of persons with disabilities.

Both protests were analysed through different axes, yet the strike aspect itself was not analysed so far. Our input into the research on both protests moves the debate onto the meaning of use of the term "strike". We elaborate on the argument of "strike takeover" and the blurring of the division between the production and reproductive labour as it was initially discussed by Kubisa in her essays on the Polish Women's Strike (Kubisa 2016a, 2017). We broaden this argument by adding the analysis of the protest of parents of persons with disabilities. We use the tools of industrial relations research and a feminist framework that recognizes social reproduction as a domain of exploitation and struggle, in order to to answer the following research questions: Were the Polish Women's Strike and the Protest of Parents of Disabled Persons a strike? What are the implications of those protests for the understanding of a strike from an industrial relations perspective and feminist perspective?

\section{Methodology and analytical framework}

For the purpose of the analysis, we focus on four cases of the Polish Women's Strike: Black Monday on the 3rd of October 2016, International Women's Day on the 8th of March 2017, the anniversary of Black Monday on the 3th of October 2017 and Black Friday on the 23rd of March 2018; and on the protest of Parents of Disabled Persons: 18th of April -27 th of May 2018. Using the method of content analysis (Babbie 2013, Silverman 2018), we collected media materials according to following criteria: interviews with the leaders and active participants of both protests in the form of written interviews and video, and media commentaries and descriptions of the protests. We collected data on the Polish Women's Strike from 13 media materials on 2016 protest, 15 media materials on 2017 protest, 8 on 2018 protest and 24 on the Protest of Parents of Disabled Personss (see Annex). The material was searched and categorised on the basis of the criteria of the presence of "strike" terminology, description of actions, attitudes of leaders and participants and the sequence of events. The material was acquired via online search with combined keywords: "strike", "Polish Women's Strike", and 
"protest of carers of persons with disabilities". The data was organized in a grid represented by a matrix with rows containing consequent protests and columns containing analytical categories derived from strike definitions. Our research strategy was based on a search for representations of the strike according to the analytical framework on which we elaborated..

In order to meet the aim of the article, we analyse both protests through the lens of a strike as an industrial action. We apply the industrial relations framework of strike analysis in order to analyse potential consequences of the free use of terminology from one domain in another domain, both for a social movement and for the industrial relations discourse. Based on sociological definitions of strike by Kałuszka and Szymański (1982) and Sociology of Work Encyclopedia (Smith 2013) and Polish law (Ustawa 1991), we identify certain characteristics of a strike:

1. A workers' strike is a collective, agreed upon action. Analysing data, we focused on the scale and group dynamics, solidarity and communication aspects of the protest.

2. A workers' strike is an act of disobedience conducted by employees. By law a strike is organized by a trade union that represents workers. For the purpose of the analysis of collected data, we asked who were the organizers and participants of the protests, who were the representing and negotiating bodies. We also asked who could participate in the protests, and whether there were any participation criteria.

3. A workers' strike is an action of refusal of work that aims at production stoppage. We discussed what is the definition of work that participants use and what strategies and tactics they use to refuse that work.

4. A workers' strike is an act of grievance. The strike has its goals and demands. In this context, we investigated the demands of the protesters and their development over time.

5. A workers' strike is an ultimate action and is preceded by negotiations and mediations. We asked about the history of protests, the duration of conflict and previous actions of the protesters.

6. A workers' strike always is organized against an employer or state, so it has certain recipients for its demands. For the purpose of the research, we asked who were the recipients of the protesters' demands.

For our analytical framework, we transpose these categories defining workers' strikes to the analysed protests. We investigate whether the characteristics of industrial actions can be found in features of women's and disable persons' parents strikes by searching for distinctions of strikes in research material, especially in the testimonies of strike participants reported in the media.

The use of the word "strike" in the case of both protests suggests that they produced their own definitions of labour. By using the analytical framework of industrial relations, we show how labour was defined by the protesters and in what forms they were trying to refuse 
to work. We investigate the consequences of those notions of labour for feminism and for industrial relations.

\section{Results}

\section{Strike as a collective action}

A strike is an agreed, collective action of workers, where by collective action we mean "action taken by a group (either directly or on its behalf through an organization) in pursuit of members' perceived shared interests" (Marshall 2003). A strike by Polish law can be organized only by a trade union, that is why it is collective action per se.

The Women's Strike was coordinated by an informal group, the Polish Women's Strike, but various events were organized by different informal organizations. In this manner it was a collective and agreed action, though most participants joined spontaneously not through organizations, rather through social media callouts and campaigns. Given the mass mobility of the actions and their mostly outdoor, public character, the Women's Strike more closely resembled a civil society protest.

The coordinating organization - the Polish Women's Strike and its local committees did not resemble a trade union as strike organizer. The groups were informal and spontaneously formed through social media. The groups did not have formal democratic character and were coordinated by activists that were not chosen as representatives, but rather volunteered to take responsibility either for media campaigns or organizing national and local events on the ground.

Formal and informal groups joined the protests and were organizing various activities during the protests. Some registered pickets, others initiated civil disobedience through road blockades; there were flash mobs, concerts, common singing, readings, lectures, discussions, collective arts and crafts activities and banner preparations. The Women's Strikes were open to different activities and OSK members collected and posted them as event programs including location and time. On the one hand, the protests were spontaneous and had a greatly participatory character; on the other hand, they were well coordinated on a local and national scale.

What was exceptional for the women's rights protest were the numbers. The issue of reproductive rights and reproductive labour had not engaged that number of protesters to this scale in Polish history. The first Women's Strike on the 3rd October 2016 gathered between 100 to 200 thousand protesters in the streets over 140 towns and cities all over Poland (Kubisa 2016, OSK, n.d., CBOS 2016). The strike on the 8th of March 2017 and the anniversary of the first strike on the 3 rd of October 2017 were both organised in over 80 cities and towns. The 
Black Friday protest of the 23rd March 2018 was held in over 20 towns and cities but the main demonstration in Warsaw gathered almost 90 thousand participants (Szczęśniak 2018b).

The women's strike participation was not exemplified only through rallies, pickets and demonstrations. Many women expressed their solidarity with the protests by wearing black clothes. For example, during the first strike of 2016 around half a million women wore black clothes to express support for the strike (OSK). This online protest participation is a new trend that was not possible before social media expansion. In addition, the range of social media action broke Polish records, generating 44 million reach of \#BlackProtest hashtag and additional 14 million for \#BlackMonday. \#BlackProtest hashtag was the most popular hashtag on Polish social media in 2016 (Polityka w sieci 2016).

The protest of Parents of Persons with Disabilities was not a mass protest, but it also should be regarded as a collective action. Though informal, the group acted as trade union representing workers in industrial conflict. It was well organized; the actions and strategy of the group seemed agreed upon; and the group had collective demands and lead speakers that presented group demands to the media. The occupying group was representing a broader social group of parents of persons with disabilities, taking action on behalf of 288 thousands family carers of adult people. (Szczerbiak 2018)

The protest of Parents of Disabled Persons was supported by various allies such as informal groups and collectives. Support pickets and demonstrations that were held in front of the Sejm building resembled "standing at the factory gate" - demonstrations held by families and members of the community during sit-down workers' strikes. This kind of support action is well recognized in Poland and became especially popular during the strikes of Solidarity in the 1980s. Standing at the factory gates shows support to striking workers but also puts additional pressure on the recipients of the demands. In the case of the protest of Parents of Disabled Persons, this kind of action also gave the other parents of persons with disabilities the possibility to participate and express their demands, not only by joining the occupation which was prevented by the Parliamentary Guard.

In the context of this article, it is worth mentioning that the strikes were not widely supported by trade unions. The Women's Strike was supported by and officially participated in an organized manner by the independent union Workers' Initiative. Letters of support were issued by the Union of Polish Teachers (along with ideas on what can be done to support the action without leaving the workplace) and All-Poland Alliance of Trade Unions just before the start of strike on the $3^{\text {rd }}$ of October 2016. Forum Związków Zawodowych pointed out that abortion is a matter of individual views. NSZZ Solidarność's catholic profile was generally contradictory to the values of the Polish Women's Strike. The protest of Parents of Disabled Persons was supported by the Workers' Initiative, the Union of Polish Teachers, All-Poland Alliance of Trade Unions and Trade Union of Psychologists and non-organized workers of 
Polish Theater in Poznań. However, most of this support was declarative and did not translate into participation in demonstrations or pickets.

\section{Strike participants}

In terms of subject criteria, a workers' strike can be only by wage workers. In terms of institutional criteria, workers' strikes can be organized only by a trade union after meeting a number of formal norms as parley, mediation and referendum.

The Women's Strike did not established any formal criteria to participate and claimed to represent all women, but there were many practical problems with participation. Generally speaking, women that worked under an employment contract could refuse work in legal way. Only an employment contract offers the possibility of leave on request, child care day or a day off due to blood donations - the three most used tools for wage worker to organize a strike without executing strike procedure. Precarious jobs are widespread in Poland, with over 1.2 million workers (7,7\%) employed on the basis of civil contracts (GUS 2018a) and over 2.2 million (13\%) self-employed outside of agriculture (GUS 2018b). This leaves almost 2.5 million workers without the possibility to participate legally in the strike by using Labour Code tools. Some of the civil contract workers and self-employed decided not to deliver services and stopped economical activity for the days of protests.

Another form of protesting during the Women's Strikes was participation in demonstrations. Demonstrations were formally open to everybody. Women who wanted to participate could face obstacles to not being able to stop care work on dependent persons such as children, disabled or elderly people. Moreover, though demonstrations were held in many towns and cities, many women could face troubles with getting into the place of events. This is true especially for people living outside big cities and in villages, as 13 million people in Poland live in counties without locally organized public transport (Dulak, Jakubowski 2018). Going to a nearby town or city depends on private cars or market-oriented private lines that do not tend to stop in remote areas.

Social media actions gave the widest possibility to participate in protests, including those who could not participate in demonstrations or could not refuse wage-work. Hashtag feminism is used to draw attention to political problems, unite activists, and creates a positive and safe space for women (Chen, Pain, Barner 2018).

The occupation of the Sejm was conducted by a specific, small group. The protest was started by 18 people - members of an informal group Parents of Disabled Persons (RON). It was impossible to join the protest after the initial group started the occupation, since the Parliamentary Guard stopped visits for the public (Kowalski 2018). A sit-in protest would not be possible for many disabled persons and their parents. People using specialized equipment, 
especially electronic devices, would not be able to participate. In addition, parents of persons that need constant care, or who could not delegate their responsibilities would be excluded. Limited access to the protest was also caused by holding the protest in one city - Warsaw. Many people willing to participate could not come as the journey requires time, economical costs and for many disabled persons traveling is not possible due to health issues.

Support actions and demonstrations that were held outside the building were more accessible and open to everybody that wanted to join. Thanks to this form of supporting protest, other parents of persons with disabilities that did not take active part in occupation came to the location, sometimes from other towns and cities outside of Warsaw and could express their support and tell their stories of non-wage care labour. The pickets gathered from dozen to several dozen people a day. Similar solidarity actions took place in other cities in Poland. Another form of participation and support for the protest was activity in social media in the form of daily updates posted by organizers and by support groups, and of the hashtag action \#supermatki that enabled virtual participation of carers who could not join the protest due to care work obligations and the severe state of the health of persons with disabilities.

\section{Strike as a refusal of work}

In the case of both protests, labour was defined both as productive and reproductive. The latter meant having and raising children, care work performed for family as well as all household chores. Organizing legal workers' strikes was impossible due to a restrictive Polish law. As mentioned above, legal workers strike can be organized only by trade unions and can refer only to specific workplace issues such as wage and labour conditions. The Women's Strike participants chose to refuse two kinds of labour, both paid work and reproductive labour. In order to refuse work, the participants of the protests used other legal ways - leave on request, a day for child care or blood donation. Those who could not use those methods - for example, because of precarious employment under a civil contract that does not guarantee the options mentioned - emphasized their support for the strike by wearing black clothes to work. Some women even faced repercussions for doing so, as it was interpreted by employers as manifesting political views in a politically-neutral work environment. (Makowski 2017, Szewczyk 2017)

Organizers encouraged others to refuse non-wage work as well. Refusal of reproductive and care work manifested in summons to transfer responsibilities to men - fathers of children, husbands and partners for the events of strike. Some women refused the unpaid work in practice by attending several hours of rallies and meetings, while leaving their children with men; others took their children with them for demonstrations and other events. Women who refused wage and non-wage work engaged in mutual, joint activities. Especially during the first Women's Strike on the 3rd of October 2016, there were callouts to spend the time of the strike 
in a useful manner through collaborative embroidery, visits to dog shelters, blood donations, participation in various lectures and discussions. Public space blockades and public service disturbances were an important aspect of the protests. Participants of the Women's Strike events were using performances and sit-ins to disturb car and public transport movement, especially during early rush hours, which caused delays and traffic. This resembled the strategy of a sit-in strike that aims to stop workplace performance by occupation of the space and stoppage of suppliers and distributors to enter workplace premises. Men in different cities organized support groups that took care of children or provided food and hot beverages for striking women. Individuals also expressed their support for the strike by taking care of their own children during the protest, taking pride in the fact and spreading it through social media.

For parents of persons with disabilities, the daily activities of care are private emotions and a full-time job at the same time. They provide care which can be characterised as work, including emotional care, food preparation, hygiene and medical care. However, their benefits and working conditions are not regulated by any regulations that apply to paid work and their $24 / 7$ efforts are privatised by the state. This kind of work is strongly connected to the emotional bond between caregiver and care receiver. It is impossible to refuse this kind of work as refusal would be aimed against the most vulnerable people.

The refusal of work by parents of persons with disabilities was performed by refusing to do it in limited, imposed spaces - at home. The refusal of work meant that it was transferred from a private, hidden space to the public space of the Sejm building. The occupation of a public building also meant a decision of resignation from part of the care work. Participants of the protest did not receive the required rehabilitation and medical care. Parents did not perform household chores such as cleaning and cooking. The occupation also meant the disturbance of work of one of the most important national institutions. As in the case of the Women's Strike, the Parents of Disabled Persons protest meant that part of the administrative and legislative work of a public institution was disturbed and slowed down. The occupation was even more significant as it was hold during a NATO summit in the Parliament.

\section{Strike demands}

Traditionally, strikes are organized in order to improve the conditions of work and increase wages. The Women's Strikes started as a defensive strike against the restriction of the abortion law and as a defence of existing rules. Very quickly the demands widened to cover various social issues including unpaid care and reproductive work.

In early 2017, a new initiative, "Save the Women 2017” (Ratujmy kobiety 2017), started working on a citizen legislation initiative to liberalize the existing abortion law. The initiative mobilized hundreds of women to gather the required one hundred thousand of signatures on 
the streets of Polish cities. At the same time, the first economical and social issues concerning reproductive work had been raised. The statement of the Polish Women's Strike from March 2017 said: "We demand improvement of the economical situation of women. We strongly disagree with the preservation of existing systemic inequalities between genders" (OSK). A year later in March 2018 the demands already included wage and benefits demands as medication cost refunds for people after organ transplantations, changes in the Alimony Fund or 500 PLN benefit for single parents.

The strike of parents of persons with disabilities was an offensive strike from the beginning and concerned issues of work conditions and wage. The main demand was introducing a new social benefit for disabled persons in the amount of 500 PLN, with reference to 500 PLN benefit that parents of minors receive. Protesters also demanded an official social minimum for a household with disabled persons and full refund of costs of diapers, medication and other equipment required in everyday life.

\section{Strike as ultimate action}

Strike is an ultimate form of industrial action and has to be preceded by a formal collective dispute of organizing, parley, mediation and referendum. Both the Women's Strike and the strike of parents of persons with disabilities were preceded by prior actions. The feminist movement in Poland tried to change the abortion regulations several times since the law was restricted in 1993. For the last time before the first strike on the 3rd of October 2016, the project of Save the Women was rejected by Parliament on the 23rd September 2016, which initiated the massive action of the Women's Strike.

The same applies to the protest of Parents of Persons with Disabilities. Their occupation of the Sejm building was a renewal of the previous protest that was suspended in 2014. Both protests of 2014 and 2018 were preceded by months of negotiations between the protest groups and the public administration.

\section{Strike against whom?}

According to Polish law, the recipient of the strike demands can only be an employer and the conflict can only be organized around issues concerning the workplace. Despite that, as it is practiced around the world, there were historical workers' strikes directed toward the government. Usually those protests were conducted by well-organized occupational groups within specific industries like miners or teachers. The recipient of the demands of both the women's and the parents' protests was the government, as it is hard to define and strike against the "employer" of reproductive and care work. The state though was defined as the organizer 
of the conditions of reproductive work. In the case of the Women's Strike, the recipient of the demands were also the Polish Catholic church and the ruling party Law and Justice (Prawo i Sprawiedliwość - PiS).

Workers participating in strikes often face repercussions from employers. This was also the case for some participants of the Women's Strikes. Reprisals included demotion to lower level jobs or even termination of contracts (Suchanow 2017). For example, 10 teachers from Zabrze faced disciplinary action for wearing black clothes to work during protest (Woźnicki 2017). Other kinds of action against the participants of the parents of persons with disabilities strike. They received 24 months prohibition from entering the Parliamentary premises. This prevents them from participating in various parliamentary commissions and meetings on new legislation concerning disabled people (Dziennik 2018).

\section{Discussion}

The analysed protests fulfilled many of the strike characteristics. They were collective actions: led by many people who shared the same agenda but not organized by any formal organization. The group that represented the Parents of Disabled Persons resembled a trade union more than groups coordinating and participating in the Women's Strike, especially the OSK which identifies itself as a coordinator and not a representative of protests. In terms of trade union representation, both protests did not get significant trade union support, except from the independent union Workers Initiative that actively participated in both protests.

In terms of the participants of the strike, the protest of the Parents of Persons with Disabilities took a more traditional form. The group was consistent and identifiable compared to the Women's Strike participants. Only the supporting events, such as pickets and demonstrations in front of the Parliament building, were more diverse, gathering various organized and unaffiliated participants. At the same time, the Women's Strike was more spontaneous and diversified per se, resembling a civil action more than a workers' strike.

The same relates to the requirements to participate. The protest of Parents of Disabled Persons resembled a trade union action. In order to participate in the group occupying Parliament, one had to be a member of the initiating informal organization RON that started the sit-in strike. This group consisted of parents of persons with disabilities and the persons themselves. It was not formed ad-hoc. Although informal, it had a long history of representing the needs of family caregivers in front of public bodies. In addition, because the work done by the parents of persons with disabilities is not recognized as work by the labour code, the refusal of work did not need to fulfill the formal requirements of an industrial action.

Participation in the Women's Strike was not formally restricted. Anybody could join, regardless of identity or membership status. But because the protest was not recognised as an 
industrial action by Polish law, many faced problems getting off work. Most participants used individual legal tools of work absence, although the scale is difficult to estimate.

Pickets, demonstrations and other events that did not require leaving wage work (since they usually were held after traditional working hours) were more widely participated in. Nevertheless participation in public events such as pickets and demonstrations required going out of the home, so still they were difficult to attend by woman performing non-wage reproductive or care labour. The social media protest had the widest range. It is not a novelty though, and there have been several social media calls to actions during classic industrial conflicts over the past few years, like the workers' strike in the coal mines in 2015 or the recent 2018 LOT Polish Airlines strike, gathering supporters through selfies, hashtags and on-line discussions. Although not new in form, the women's protest had an unprecedented scale of thousands of participants on social media generating somewhere in the range of several million recipients.

Formally, it was more difficult to refuse to work during the Women's Strike, as it was considered a protest of individuals by Polish law and was not organized by trade unions according to the complicated collective bargain procedure. Participants usually used individualised tools to refuse wage work. Interestingly, many employers - from local government offices to big and small private enterprises such as shops, restaurants and media corporations - supported the women's protest (Newsweek 2016). This is controversial since the essence of a strike is class conflict represented by the collective struggle of wage workers against their employer or the state, which organizes the conditions of work. The fact that employers "gave permission" to strike or even encouraged participation in various events is what marks the most Women's Strike as different from industrial conflict.

The refusal of unpaid work was different, organized on an individual level and according to different patterns - from the refusal to perform any reproductive work to changing its conditions (like taking children to the demonstration). Parents of persons with disabilities could not refuse work, so they moved it from the private to the public space in order to make it recognized. They used a strategy traditional in industrial conflicts, the sit-in strike, just outside their "factory" but inside the public building.

Both protests disturbed the work of public institutions and blocked public spaces which is a well known tactic of workers' protests, especially in contemporary Poland, where a strike action is unavailable for many groups of workers for formal reasons. The most famous demonstrations and occupations in recent Polish history were made by nurses (Kubisa 2014), coal miners (Kubisa 2016b), and teachers (Czarzasty 2017). Both protests were preceded by attempts at negotiation and other forms of resistance. A strike was seen as the ultimate action, after exhausting other options of dispute with government. 
Finally both protests were not aimed towards any particular employer but the governing bodies - the government, politicians, the ruling party and, in the case of the Women's Strike, the Catholic Church as well. It is against Polish law but in line with the tradition of workers movements to raise demands directly to the state as the regulatory body of the social system and living conditions.

The focus of the article is on the basic question: what does it mean exactly that the Polish Women's Strike and the Protest of Parents of Disabled Persons in 2016, 2017 and 2018 were called strikes? Our first research question - was it a strike? - has a double answer. Both protests have much in common with the trade unions who lead a traditional workers' strike. The similarities include the collectiveness of action, forms of work refusal, and the demands concerning living and work conditions. The differences arise from both the legal and organisational conditions as well as the type of work performed - unpaid reproductive and care work. Therefore, it was a strike as an idea, but not as a tool. A strike as an idea empowered reproductive labour and care work. Both protests can be seen as step further from the politicization of care as described by Briskin because they make care and reproduction in the private sphere political. The organizers and the participants of both protests made efforts to make the actions inclusive, recognizing the specific character of reproductive and care work. In the case of the Women's Strike, the inclusive character was achieved by online hashtag action. The protest of persons with disabilities and their carers was very exclusive in terms of participation, as not even every person with a disability or their carers could participate due to the physical, emotional and geographic constraints. This was overcome to some degree in the form of online participation. We interpret those inclusive actions as a recognition of the specifics of reproduction and care work and adjusting the profile of the strike for the participants.

However, a strike as a real tool did not take place because the refusal of work was never fully performed. Paid work was not fully refused due to legal constraints. In the case of reproductive and care work, both protests showed that they are very difficult to refuse. The strike framework shows its limitations when the axis of conflict is analysed more precisely. Both protests were directed at the state and its institutions. However, the direct care relation between the caregiver and care receiver in the private sphere, both in the case of the women's protest and RON protest, differ substantially from the protests related to class conflicts in productive labour. This observation can be further strengthened if we look at cases of the refusal of care work in paid work, under the framework of the politicization of care. In the Polish context, nurses on strike refuse to work but at the same time are ready to help in case of an emergency (Kubisa 2014). The recommendation of Silvia Federici (2008) of striking against the exploitation, not the people in care relationships, proved to be hard to put into practice. While the participants recognized the gendered nature of the state (Walby 1990,1997), 
represented by the public authorities and government and were able to elaborate on the strike demands, they never fully stopped performing reproductive and care work. However, they performed it on their terms, which was especially visible in case of the protest of persons with disabilities.

The answer to the second research question - What are the implications of this for the understanding of a strike from an industrial relations perspective and feminist perspective? is also complex. The participants and main speakers of the Polish Women's Strike made no references to the older international women initiatives such as Global Women Strike, initiated in 2000 as an international action for wages for the domestic work of housewives subsidized by the state budget instead of army-focused expenses (James 2018). The topics raised in the discussion on the value and importance of reproductive labour and its relation to capitalism, formulated by Silvia Federici, for example, were not referred to. The concept of unpaid domestic work is generally recognized in Poland. The Polish Women's Strike was the first wide application of the term strike to reproductive labour and reproductive rights. There were incidents before, like Fundacja Mama's "Mothers' Strike” picket on the 26th of May 2008 in Warsaw, but never on such a scale. The use of the term "strike" brought empowerment to reproductive labour and a new form of agency to the participants - they not only formulated their demands as social movements do, but also performed their agency by active refusal. For social movements, strike rhetoric is a new idea of action, much needed in long-standing struggles. The demands of both protests were focused around the recognition of reproductive work as work and economic issues. By using the term "strike", protesting women gave a new axis to the abortion rights debate, pointing out the direct connection between reproductive rights, reproductive labour and production. Parents of Disabled Persons formulated demands that were directly connected to productive work, even though they referred to care work performed in the private sphere. They demanded benefits and medical supplies that would make their work less expensive. Both groups struggled against the privatisation of public services and demanded the state's support towards disempowered groups.

An industrial strike action is considered as the ultimate, radical, almost vulgar form of protest. The direct reference to the idea of a strike emphasizes the ultimate character of both protests and is a touchstone for the scale of the social conflict and determination of the protesters. The use of strike terminology in a new context overruled the usual anti-strike mocking discourses present in public debate. Therefore, the use of strike terminology has vital consequences for industrial relations in Poland and the trade unions' agenda. The link between reproductive labour and the strike, seen in the case of both protests and socially accepted, could be recognized by the trade unions also. Support and participation in the protests of some trade unions can be seen as the beginning of a process of recognition for non-wage care and reproductive work as labour. Even though trade unions could not organize such strikes due to 
formal reasons, they could express their support in the form of statements or legal advisories. The possibility of the extension of forms of support for protests in the domain of reproductive labour forms a new field for discussion, both in terms of the collective bargaining legislation, which prohibits political strikes, and in the broader terms of trade unions' social, economic and political agenda. Such actions have already been undertaken by some foreign unions. For example, in 2016 all major trade unions in Spain called for a two-hour strike in all unionized workplaces in solidarity with the Women's Strike and two radical trade unions, CNT and CGT, called for 24-hour action (Garcia, Alabao, Perez 2018). Moreover, international union federations like ITUC (International Trade Union Confederation) for years have trained their members on issues of recognition and equal share of unpaid work between men and women (ITUC 2008). Support for the Women's and Parents of Disabled Persons Strikes seems to be indicator of such changes in the Polish trade movement.

\section{Conclusion}

Both analysed protests can be characterised as strikes only partially if the formal legal aspects are put aside. However, we may describe them as a kind of "strike takeover" because not only the strike idea was used outside the factory gates, but it was used in the context of reproductive labour. The participants politicized care and reproduction and the use of strike terminology broadened their agency. The Polish Women's Strike events weren't strikes de jure, however they still built upon the notion: "I disagree, therefore I don't work". They rejected the division between production (wage labour) and reproduction (non-wage labour), which gave a deeper meaning to the "refusal of work", showing how closely they are interconnected, both in terms of reproductive rights and of care work. The empowerment of this event was derived from taking over the concept of the strike and providing an inclusive space to connect different actions related to the struggle for reproductive rights. In the case of parents of persons with disabilities the "refusal of work" can be interpreted as the refusal of performing reproductive work on the margin of the private sphere. In this case, striking is not a refusal of work but the contrary - a demonstrative public performance of work that is usually hidden.

The idea of the strike proved to be socially needed and the form and realisation of protests proved interdisciplinary potential. We interpret this as a strategy of appropriation of typical protest actions reserved for wage labour. The use of the strike framework to analyse social protests enables to better understand their dynamics and limitations. It is therefore clear that what is the biggest strength of the protest, which is reproductive labour, is its weakness, because of the limitations of the refusal of reproductive work. Nevertheless, the "strike take over" for the purpose of reproductive labour creates a new context for the actions of industrial relations actors, especially trade unions. 


\section{References}

Babbie, Earl. 2013. Podstany badań społecznych. Trans. W. Bertkiewicz. Warszawa: Wydawnictwo Naukowe PWN.

Bakalarczyk, Rafał. 2018. “Co dla osób niepełnosprawnych.” Kwartalnik Wię́ May 13. Retrieved from http://wiez.com.pl/2018/05/13/co-dla-osob-niepelnosprawnych/.

Briskin, Linda. 2013. "Nurse Militancy and Strike Action." Workers of the World-International Journal on Strikes and Social Conflicts 1(2): 105-134.

Brecher, Jeremy. 2014. Strike! Revised, Expanded, and Updated. Oakland: PM Press.

Burns, Joe. 2011. Reviving the right to strike. Brooklyn: Ig Publishing.

CBOS. 2016.. Polacy o prawach kobiet, "czarnych protestach" i prawie aborcyjnym. Komunikat z badań nr 165/2016. Warszawa.

Chmielewska, Marta, Małgorzata Druciarek and Izabela Przybysz. 2017. Czarny protest: $w$ strone nowego "kompromisu aborcyjnego"? Instytut Spraw Publicznych. Retrieved from https://pl.boell.org/sites/default/files/isp_hbs_czarny_protest_kompromis_aborcyjny .pdf (accessed 15.04.2019).

Czarzasty, Jan. 2017. Poland: Government enacts radical education reform despite opposition. Retrieved from https://www.eurofound.europa.eu/publications/article/2017/polandgovernment-enacts-radical-education-reform-despite-opposition (accessed 15.04.2019).

Dalla Costa, Mariarosa. 1972. The power of women and the subversion of the community. Bristol, UK: Falling Wall Press.

Dialog. 2019. Podstawowe pojecia. Dialog społeczny. Retreived from: http://www.dialog.gov.pl/czym-jest-dialog-spoleczny/podstawowe-pojecia/ (accessed 15.04.2019).

Dulak, Maciej and Bartosz Jakubowski. 2018. "Publiczny transport zbiorowy w Polsce. Studium Upadku." Klub Jagielloński. Retrieved from https://klubjagiellonski.pl/2018/04/17/publiczny-transport-zbiorowy-w-polscestudium-upadku/ (accessed 15.04.2019).

Dziennik. 2018. “Uczestnicy protestu opiekunów osób niepełnosprawnych z zakazem wejścia na teren Sejmu. Do 2020 roku." Driennik.pl. Retrieved from https://wiadomosci.dziennik.pl/wydarzenia/artykuly/577843,uczestnicy-protestu-ronz-zakazem-wejscia-na-teren-sejmu.html (accessed 15.04.2019).

Duffy, Mignon. 2007. "Doing the dirty work. Gender, Race, and Reproductive Labor in Historical Perspective." Gender \& Society, Vol. 21 No. 3: 313-336.

Federici, Silvia. 1975. Wages Against Housework. Bristol-London: Power of Women Collective and the Falling Wall Press.

Federici, Silvia. 2008 Precarious Labour. A Feminist Viewpoint. https://inthemiddleofthewhirlwind.wordpress.com/precarious-labor-a-feministviewpoint/ (accessed 28.03.2019).

Fraser, Nancy. 2016. “Contradictions of Capital and Care.” New Left Review vol. 100. 
Garcia, Alabao, Perez. 2018. "Spain’s Feminist Strike.” New Left Review vol. 110.

Graff, Agnieszka. 2001. Świat bez kobiet. Pleć w polskim życiu publicznym. Warszawa: Wydawnictwo W.A.B.

GUS. 2016. Matżeństwa oraz drietność w Polsce. Retrieved from https://stat.gov.pl/files/gfx/ portalinformacyjny/pl/defaultaktualnosci/5468/23/1/1/malzenstwa_i_dzietnosc_w_p olsce.pdf (accessed 06.01.2019.)

GUS. 2018a. Pracujacy w gospodarce narodowej w 2017 roku. Retrived from:_http:/ / stat.gov.pl/ obszary-tematyczne/rynek-pracy/pracujacy-zatrudnieni-wynagrodzenia-kosztypracy/pracujacy-w-gospodarce-narodowej-w-2017-roku,7,15.html (accessed 06.01.2019).

GUS. 2018b. Pracujacy na wtasny rachunek. Retrived from: https://stat.gov.pl/obszarytematyczne/rynek-pracy/pracujacy-zatrudnieni-wynagrodzenia-koszty-pracy/pracujacyna-wlasny-rachunek,14,1.html (accessed 06.01.2019).

Hartmann, Heidi. 1976. “Capitalism, patriarchy, and job segregation by sex.” Signs: Journal of Women and Culture in Society 1 (3): 137-169.

Hołub, Jacek. 2018. Żeby umarło przede mna. Opowieśsi matek niepetnosprawnych dzieci. Wołowiec: Wydawnictwo Czarne

Hyman, Richard. 1990. Strikes. London: Macmillan.

ITUC. 2008. Achieving Gender Equality. A Trade Union Manual. Retrieved from https://www.ituc-csi.org/IMG/pdf/manuel_ENGOK.pdf.

James, Selma. 2018. "Decades after Iceland's »day off«, our women's strike is stronger than ever." The Guardian March 8.

Kacpura et al. 2016. Twenty years of anti-abortion law in Poland. Retrieved from http:// federa.org.pl/wpcontent/uploads/2013/07/report_federa_20_years_polands_abortion_law.pdf (accessed 15.04.2019).

Kałuszka, Jacek and Szymański Piotr. 1982. Zwiqzki, strajki, negocjacje. Warszawa: Młodzieżowa Agencja Wydawnicza.

Korolczuk, Elżbieta. 2018. “Czarny Piątek jako pożegnanie z Kościołem.” Krytyka Politycz̨na March 26.

Korolczuk, Elżbieta. 2016. "Explaining the »Black Protests« in Poland: The Power of Connective Action." Zoon Politicon vol. 7.

Kowalski, Roch. 2018. "Polacy świętują 3 Maja, a w Sejmie... »dzień zamknięty«. Po raz pierwszy od 2008 roku." Tok FM. Retrieved from_http://www.tokfm.pl/Tokfm/ 7,102433,23350803,po-raz-pierwszy-od-lat-w-swieto-konstytucji-sejm-zamkniety.html (accesed 15.04.2019).

Król, Agnieszka and Pustułka, Paula. 2018. "Women on strike: mobilizing against reproductive injustice in Poland." International Feminist Journal of Politics vol. 20, issue 3. 
Kubisa, Julia. 2018. “Ufajmy kobietom.” Krytyka Polityczna March 27. Retrieved from http://krytykapolityczna.pl/kraj/julia-kubisa-czarny-piatek-ufajmy-kobietom/ (accessed 15.04.2019).

Kubisa, Julia. 2014. Bunt białych czepków. Analiza dzia talności zwiazkowej pielegniarek i położnych. Warszawa: Wydawnictwo Naukowe Scholar.

Kubisa, Julia. 2016a. “Odzyskajmy Polskę dla kobiet.” Krytyka Politycz̨na October 10. Retrieved from http://krytykapolityczna.pl/kraj/odzyskajmy-polske-dla-kobiet/ (accessed 15.04.2019).

Kubisa, Julia. 2016b. "Gendered division of trade union protests. Strategies, activities and outcomes of union activity among miners and nurses in Poland." Transfer: European Review of Labour and Research vol. 22, issue 3: 331-345.

Kubisa, Julia. 2017. “We Will Not Close Our Umbrellas!” Obieg. vol. 3.

Leśniewicz, Kacper. 2016. "Czarny protest w małych miastach.” Tygodnik Przeglad October 10. Retrieved from https://www.tygodnikprzeglad.pl/bunt-kobiet/ (accessed 15.04.2019).

Majewska, Ewa. 2017. Tramwaj zwany uznaniem. Feminizm i solidarność po neoliberalizmie. Warszawa: Instytut Wydawniczy Książka i Prasa.

Majewska, Ewa. 2018. Kontrpubliczności ludowe i feministyczne. W czesna „Solidarność” i czarne protesty. Warszawa: Instytut Wydawniczy Książka i Prasa.

Makowski, Jarosław. 2017. “Bo bluzka była czarna? Warto protestować!” Newsweek Polska February 10. Retrieved from_https://www.newsweek.pl/opinie/nauczycielkioskarzone-za-udzial-w-czarnym-protescie/fygb3fn (accessed 15.04.2019).

Marshall, Gordon. 2003. Dictionary of Sociology. Oxford: Oxford University Press.

Masewicz, Walery. 1986. Strajk. Studium prawno-socjologicæne. Warszawa: Instytut Wydawniczy Związków Zawodowych.

Mrozek, Witold. 2018. “Ćwierć wieku zakazu aborcji.” OKO.Press. Retrieved from https://oko.press/cwierc-wieku-zakazu-aborcji-25-temu-sejm-przyjal-jednanajbardziej-restrykcyjnych-ustaw-europie-popieral-ja-komorowski-przeciw-byl-tusk/ (accessed 15.04.2019).

Nakano, Glenn Evelyn. 1992. "From servitude to service work: Historical continuities in the racial division of paid reproductive labor." Signs: Journal of Women in Culture and Society 18: $1-43$.

Newsweek. 2016. "Strajk kobiet i \#czarnyprotest. Co na to pracodawcy." Newsweek Polska September 30. Retrieved from_https://www.newsweek.pl/polska/strajk-kobiet-iczarnyprotest-co-na-to-pracodawcy/shsxwlk (accessed 15.04.2019).

OSK. n.d. Retrieved from http://strajkkobiet.eu/wp-content/uploads/2018/10/000.png (accessed 15.04.2019).

Pacewicz, Piotr. 2018. "Jakub Hartwich i Adrian Glinka bronią swoich matek po brutalnej akcji strażników. »Nie jestem ubezwłasnowolniony i mam prawo«.” Oko.press May 25. Retrieved from_http://wiadomosci.gazeta.pl/wiadomosci/7,114883,23436052,straz- 
marszalkowska-chciala-usunac-pocztowki-dla-protestujacych.html (accessed 15.04.2019).

Politka w Sieci. 2016. “Analiza \#Czarnyprotest vs. \#Białyprotest.” Politykawsieci.pl October 5.

Retrieved from:_https://politykawsieci.pl/analiza-czarnyprotest-vs-bialyprotest/ (accessed 15.04.2019).

Secombe, Wally. 1974. "The housewife and her labour under capitalism." New Left Review 83: 3-24.

Silverman, David. 2018. Interpretacja danych jakościowych. Warszawa: Wydawnictwo Naukowe PWN.

Szczerbiak, Agata. 2018. "Czy rząd postawi na swoim proteście niepełnosprawnych?” Polityka.pl May 3. Retrived from:

https://www.polityka.pl/tygodnikpolityka/spoleczenstwo/1747414,1,czy-rzadpostawi-na-swoim-w-protescie-niepelnosprawnych.read (accessed 15.04.2019).

Szczęśniak Agata. 2018a. "Walka i nadzieja czyli co po 40 dniach walki w Sejmie.”_Krytyka Polityczna May 28. Retrieved from http://krytykapolityczna.pl/kraj/walka-i-nadziejaczyli-co-po-40-dniach-w-sejmie/ (accessed 15.04.2019)

Szczęśniak, Agata. 2018b. "Czarny piątek to coś znacznie więcej niż odrzucenie antykobiecego sojuszu Kościoła z państwem PiS.” Oko.press March 24. Retrieved from: https://oko.press/czarny-piatek-cos-znacznie-wiecej-niz-odrzucenie-antykobiecegosojuszu-kosciola-panstwem-pis/ (accessed 15.04.2019).

Szczuka, Kazimiera. 2004. Milczenie owieczek. Rzecz o aborcji. Warszawa: Wydawnictwo W.A.B. Szewczyk, Paulina. 2017. "Nauczycielki z Zabrza za udział w Czarnym Proteście zapłaciły wysoką cenę. Ale nie żałuja." Newsweek Polska October 3. Retrieved from https://www.newsweek.pl/polska/spoleczenstwo/nauczycielki-z-zabrza-za-udzial-wczarnym-protescie-zaplacily-wysoka-cene-czarny/wjqrkj6 (accessed 15.04.2019).

Smith, Vicki (ed.). 2013. Sociology of Work. Los Angeles-London-New Delhi-SingaporeWashington DC: SAGE.

Suchanow, Klementyna. 2017. "Rozpoczęły się represje wobec organizatorek Czarnego Protestu. Szykany, odmowy urlopu i zwolnienia." Polityka.pl June 24. Retrieved from https://www.polityka.pl/tygodnikpolityka/kraj/1709328,1,rozpoczely-sie-represjewobec-organizatorek-czarnego-protestu-szykany-odmowy-urlopu-i-zwolnienia.read (accessed 15.04.2019).

Tong, Rosemarie Putman. 2002. Myśl feministyczna. Wprowadzenie. Trans. J. Mikos and B. Umińska. Warszawa: PWN

Ustawa o rozwiązywaniu sporów zbiorowych. 1991. Dz. U. Z 1991 r., Nr 5, poz. 236 z późn. zm.

Walby, Sylvie. 1990. Theorizing Patriarchy. Oxford: Wiley-Blackwell.

Walby, Sylvie. 1997. Gender Transformations. London: Routledge.

Watson, Tony, J. 1995. Sociology, Work and Industry. London and New York: Routledge. 
Witkowski, Jarosław. 2012. “Charakterystyka poszczególnych (innych niż strajk) akcji protestacyjnych.” Roczniki administracji i prawa. Teoria i praktyka rok XII.

Woźnicki, Łukasz. 2017. “Władza mści się za bunt. Nauczycielki straca pracę za »czarny protest«?” Wyborcza.pl February 9. Retrieved from_http://wyborcza.pl/ 7,75398,21354569,wladza-msci-sie-za-bunt-nauczycielki-straca-prace-za-czarny.html (accessed 15.04.2019).

Wprost. 2018. "Protest w Sejmie. Hartwich: Nie możemy korzystać z windy." Wprost.pl May 26. Retrieved from_https://www.wprost.pl/kraj/10127571/protest-w-sejmie-hartwichnie-mozemy-korzystac-z-windy.html (accessed 15.04.2019). 


\section{Annex}

Adamczyk, Małgorzata and Michał Gostkiewicz. 2016. “To ona wymyśliła \#CzarnyProtest. „Mówili, że lajkami na Facebooku i czarnym ubraniem nie wygramy. No więc wygraliśmy!«. Wywiad z Małgorzatą Adamczyk.” Gazeta.pl. Retrieved from: http://weekend.gazeta.pl/weekend/1,152121,20798021,to-ona-wymyslilaczarnyprotest-mowili-ze-lajkami-na-facebooku.html (accessed 15.04.2019).

Ambroziak, Anton. 2018. "Wznawiają strajk okupacyjny Sejmu. Rodzice dorosłych niepełnosprawnych: »W 2014 roku prezes Kaczyński całował nas po dłoniach. A dziś? Jesteśmy sami«.”OKO.press April 18. Retrieved from: https://oko.press/wznawiajastrajk-okupacyjny-sejmu-rodzice-doroslych-niepelnosprawnych-w-2014-r-prezeskaczynski-calowal-nas-po-dloniach-a-dzis-jestesmy-sami/ (accessed 15.04.2019).

Bakalarczyk, Rafał. 2018. "Strajk opiekunów dorosłych osób niepełnosprawnych" [KOMENTARZ EKSPERTA]. www.domtopraca.pl April 23.

https://domtopraca.pl/strajk-opiekunow-doroslych-osob-niepelnosprawnychkomentarz-eksperta/ (accessed 15.04.2019).

Bartkiewicz, Artur. 2018. "Protest kobiet w Warszawie. Ratusz: 55 tys. uczestników." Rzeczpospolita March 24. Retrieved from:_https://www.rp.pl/Spor-oaborcje/180329654-Protest-kobiet-w-Warszawie-Ratusz-55-tys-uczestnikow.html (accessed 15.04.2019).

Buklaha, Zuzanna. 2017. “Czarny protest na Dzień Kobiet. W Warszawie pikiety, demonstracje, happeningi." Wyborcza.pl March 7. Retrieved form: http://warszawa.wyborcza.pl/warszawa/7,54420,21464742,czarny-protest-na-dzienkobiet-w-warszawie-pikiety-demonstracje.html (accessed 15.04.2019).

Chełstowska, Agata. 2016. "Historyczny Czarny Protest." Codziennik Feministyczny October 5. Retrieved from:_http://codziennikfeministyczny.pl/historyczny-czarny-protest/ (accessed 15.04.2019).

Czarnacka, Agata and Paweł Gawlik. 2016. "Strajk Kobiet. Byłyśmy na ulicach także po to, by protestować wobec fali hejtu, która spada na nas wszystkie. Wywiad z Agata Czarnacka." Wyborcza.pl. Retrieved from:_http:/ / wyborcza.pl/7,75398,20893254,strajkkobiet-bylysmy-na-ulicach-takze-po-to-by-protestowac.html (accessed 15.04.2019).

Dąbrowska, Ismena. 2017. "Czarny Protest 2017 - czyli dlaczego Polki nie składaja parasolek." Glamour.pl October 3. Retrieved from: https://www.glamour.pl/artykul/czarny-protest-2017-czyli-dlaczego-polki-nie-skladajaparasolek-171003051626 (accessed 15.04.2019).

Diduszko-Zyglewska, Agata. 2017. "9 powodów, żeby kobiety podniosły alarm.” Krytyka Polityczna October 3. Retrieved from:_https://krytykapolityczna.pl/kraj/9-powodowdiduszko-strajk-kobiet/ (accessed 15.04.2019).

Dubrowska, Magdalena. 2017. "W niedzielę Manifa, a w środę 8 marca Międzynarodowy Strajk Kobiet. Co Jest Grane? March 3. Retrieved from: 
http:/ / cojestgrane24.wyborcza.pl/cjg24/1,13,21442743,147812,W-niedziele-Manifa--aw-srode-8-marca-Miedzynarodo.html (accessed 15.04.2019).

Dzień Dobry TVN. 2018 “Iwona Hartwich: rodzic dziecka niepełnosprawnego potrafi znieść wiele upokorzeń." drieńdobry.tvn.pl June 2. Retrieved from:

https://dziendobry.tvn.pl/a/iwona-hartwich-rodzic-dziecka-niepelnosprawngo-potrafizniesc-wiele-upokorzen (accessed 15.04.2019).

Gala.pl. 2017. "Chastain, Rubik, Janda, Ostaszewska, Mołek Gwiazdy na Międzynarodowym Strajku Kobiet.” gala.pl March 8. Retrieved from:_https://www.gala.pl/galeria/gwiazdyna-miedzynarodowym-strajku-kobiet-zdjecia/martyna-wojciechowska-34 (accessed 15.04.2019).

Gazeta.pl. 2016. "Protest przed Sejmem. Wychodzi matka niepełnosprawnego 24-latka. Tego przemówienia ludzie słuchali w kompletnej ciszy." Gaz̨eta.pl October 1. Retrieved from: http://wiadomosci.gazeta.pl/wiadomosci/7,114883,20775059,protest-przed-sejmemwychodzi-matka-niepelnosprawnego-24.html (accessed 15.04.2019).

Gazeta.pl 2018. "Posłanka PiS straszy: Znalazłabym paragraf na tych rodziców, którzy przetrzymują dzieci w Sejmie.” Gazeta.pl May 8. Retrieved from: http://wiadomosci.gazeta.pl/wiadomosci/7,114884,23368316,poslanka-pisznalazlabym-paragraf-na-tych-rodzicow-ktorzy.html (accessed 15.04.2019).

Gotowalska, Żaneta. 2016. "To będzie naprawdę czarny poniedziałek.” Noižpl . Retrieved from:_https://noizz.pl/spoleczenstwo/czarny-poniedzialek-czarny-protest-o-cochodzi/7x9dzhs (accessed 15.04.2019).

Kozak, Aga and Paulina Nodzyńska. 2017. “»Czarny wtorek« w rocznicę »czarnego protestu«. Strajk kobiet w obronie praw i godności." Wyborcza.pl. Retrieved from: http://wyborcza.pl/10,82983,22464738,czarny-wtorek-w-rocznice-czarnego-protestustrajk-kobiet.html (accessed 15.04.2019).

Kozakoszczak, Agnieszka. 2017. "Dlaczego zaangażowanie osób LGBTQ w Czarny Piątek jest oczywiste?" Codziennik Feministyczny March 23. Retrieved from:

http:/ / codziennikfeministyczny.pl/dlaczego-zaangazowanie-osob-lgbtq-czarny-piatekjest-oczywiste/ (accessed 15.04.2019).

Krytyka Polityczna. 2017. "Międzynarodowy Strajk Kobiet”. Krytyka Polityczna March 7. Retrieved from:_http://krytykapolityczna.pl/kraj/miedzynarodowy-strajk-kobiet/ (accessed 15.04.2019).

Lempart, Marta and Agnieszka Kublik. 2016. "Organizatorka poniedziałkowego strajku kobiet: »Zróbmy huk na całą Polskęu. Wywiad z Marta Lempart.” Wyborcza.pl September 29. Retrieved from:_http://wyborcza.pl/1,75398,20761998,organizatorkaponiedzialkowego-strajku-kobiet-zrobmy-huk-na.html (accessed 15.04.2019).

Lempart, Marta and Karolina Kijek. 2018. "Marta Lempart o »czarnym piątku«: Cokolwiek by się działo, nie poddamy się. Nie pójdzie im łatwo. Wywiad z Martą Lempart." Wyborcza.pl. Retrieved from:

http://wroclaw.wyborcza.pl/wroclaw/7,35771,23173004,marta-lempart-o-czarnympiatku-cokolwiek-by-sie-dzialo-nie.html (accessed 15.04.2019). 
Lempart, Marta and Renata Kim. 2017. "»Nie będziemy grzeczne«. Kobiety znów wychodzą na ulice. Wywiad z Martą Lempart." Newsweek.pl. Retrieved from:

http://www.newsweek.pl/polska/spoleczenstwo/czarny-protest-2017-kobiety-walczao-swoje-prawa-wywiad,artykuly,416732,1.html (accessed 15.04.2019).

Lewandowska, Janina. 2018. "Bezprecensowe wydarzenie w środowisku osób niepełnosprawnych.” Watchdogfron.pl May 7. Retrieved from:

http://www.watchdogpfron.pl/bezprecedensowe-wydarzenie-w-srodowisku-osobniepelnosprawnych/ (accessed 15.04.2019).Lubianiec, Katarzyna. 2017. "Czarny Protest - nie składamy parasolek." Kobieta.pl. Retrieved from:

https://www.kobieta.pl/artykul/czarny-protest-nie-skladamy-parasolek (accessed 15.04.2019).

naszemiasto.pl. 2017. "Międzynarodowy strajk kobiet, 8 marca. Freedom Disco, Ściana Furii i wielki finał w centrum.” Naszemiasto.pl February 21. Retrieved from: http://warszawa.naszemiasto.pl/artykul/miedzynarodowy-strajk-kobiet-8-marcafreedom-disco-sciana,4023126,artgal,t,id,tm.html (accessed 15.04.2019).

naszemiasto.pl. 2017. "Warszawianki ponownie wyszły na ulice. »Nie możemy milczeć«." Naszemiasto.pl October 4. Retrieved from:

http://warszawa.naszemiasto.pl/artykul/warszawianki-ponownie-wyszly-na-ulice-niemozemy-milczec,4265497,artgal,t,id,tm.html (accessed 15.04.2019).

Nowacka, Barbara and Jakub Dymek. 2016. "Czarny Protest był egalitarny I solidarny. Wywiad z Barbara Nowacka." Krytyka Polityczna October 21. Retrieved from: http://krytykapolityczna.pl/kraj/nowacka-czarny-protest-byl-egalitarny-i-solidarny/ (accessed 15.04.2019).

Nowiński, Adam. 2018. “10 grzechów głównych PiS podczas strajku opiekunów w Sejmie.” natemat.pl April 26. Retrieved from:_https://mobile.natemat.pl/236695,10-grzechowglownych-pis-podczas-strajku-opiekunow-wsejmie?utm_referrer $=$ https $\% 3 \mathrm{~A} \% 2 \mathrm{~F} \% 2 \mathrm{Fwww}$.google.pl $\% 2 \mathrm{~F}$ (accessed 15.04.2019).Oleksy, Ewelina. 2016. "Czarny protest na Pomorzu. Strajk kobiet w Gdańsku i innych miastach.” Dziennik Bałtycki October 3. Retrieved from: https://dziennikbaltycki.pl/czarny-protest-na-pomorzu-strajk-kobiet-w-gdansku-iinnych-miastach-zdjecia-wideo/ar/10696654 (accessed 15.04.2019).

Orłowska, Dorota. 2018 “Czy dalej będziemy bezczynnie patrzeć na to, jak godność ludzka jest deptana?” [LIST CZYTELNICZKI]. Newsweek.pl May 17.. Retrieved from: https://www.newsweek.pl/opinie/protest-niepelnosprawnych-w-sejmie-listczytelniczki/rk83qwc (accessed 15.04.2019).

Orłowska, Dorota. 2018. "Zmusza się nas do życia w izolacji, a potem, kiedy z niej wychodzimy, lekceważy.” Polityka.pl_May 5. Retrieved from: https://www.polityka.pl/tygodnikpolityka/spoleczenstwo/1748216,1,zmusza-sie-nasdo-zycia-w-izolacji-a-potem-kiedy-z-niej-wychodzimy-lekcewazy.read (accessed 15.04.2019). 
Skrzyński, Bartłomiej and TomaszPajączek. 2018. "Bartłomiej Skrzyński: »nie mielismy sztyletów ani karabinów przyczepionych do wózków«. Wywiad z Bartłomiejem Skrzyńskim" Onet Wrocław June 2. Retrieved from: https://wroclaw.onet.pl/bartlomiejskrzynski-nie-mielismy-sztyletow-ani-karabinow-przyczepionych-do-wozkow/s7h6r5h (accessed 15.04.2019).

PAP. 2018. "Jakub Hartwich na co dzień pracuje? „To uspołecznianie” - mówi Iwona Hartwich." www.niepelnosprawni.pl May 24. Retrieved from: http://www.niepelnosprawni.pl/ledge/x/655601 (accessed 15.04.2019).

PAP. 2018. "Protestujący w Sejmie zaproponowali kompromis rządowi. Jest reakcja minister Rafalskiej." RMF 24 May 24. Retrieved from: https://www.rmf24.pl/fakty/polska/news-protestujacy-w-sejmie-zaproponowalikompromis-rzadowi-jest-r,nId,2585286 (accessed 15.04.2019).

Piekarski, Mariusz. 2018. “Spotkanie z niepełnosprawnymi bez uczestników protestu. »Kto się interesowal, to wiedział «". RMF 24 June 15. Retrieved from: https://www.rmf24.pl/fakty/polska/news-spotkanie-z-niepelnosprawnymi-bezuczestnikow-protestu-kto-s,nId,2594492 (accessed 15.04.2019).

Plura, Marek. 2018. “To co zobaczyłem w Sejmie napawa mnie grozą! Europa musi się dowiedzieć!" the fad May 18. Retrieved from: http://thefad.pl/aktualnosci/marek-plurato-co-zobaczylem/ (accessed 15.04.2019).

Polityka.pl. 2017. “»Nie składamy parasolek« - przed nami Czarny Wtorek.” Polityka.pl September 26. Retrieved from: https://www.polityka.pl/tygodnikpolityka/spoleczenstwo/1721382,1,nie-skladamyparasolek--przed-nami-czarny-wtorek.read (accessed 15.04.2019).

PolstatNews.pl. 2018. "Walczą o »godne życie swoich dzieci«. Zobaczcie, jak wygląda codzienność protestujących w Sejmie.”_wmw.polsatnews.pl April 25. Retrieved from: https://www.polsatnews.pl/wiadomosc/2018-04-25/walcza-o-godne-zycie-swoichdzieci-zobaczcie-jak-wyglada-codziennosc-protestujacych-w-sejmie/ (accessed 20.04.2019).

RodziceOzN. 2018. "Strajk opiekunów osób niepełnosprawnych”. Twitter @rodziceON May 7. Retrieved from: https://twitter.com/rodziceon/status/993445258754183168 (accessed 15.04.2019).

RON. 2018. Za niez̧ależnym życiem. Oświadcrenie.

Różańska, Daria. 2018. “»Stali się symbolem walki o godne życie«. Niepełnosprawni Kuba i Adrian to najwięksi bohaterowie sejmowego protestu."_natemat.pl May 9. Retrieved from: https://mobile.natemat.pl/237489, niepelnosprawni-kuba-i-adrian-bohaterowiesejmowego-protestu-marza-o-zalozeniu-rodziny-boja-sie-smiercirodzicow?utm_referrer=https $\% 3 \mathrm{~A} \% 2 \mathrm{~F} \% 2 \mathrm{Fwww} . g o o g l e . p l \% 2 \mathrm{~F}$ (access 20.04.2019).

Staśko, Maja. 2016. “Wolność, Równość, Aborcja.” Krytyka Polityczna September 29. Retrieved from:_http://krytykapolityczna.pl/kultura//czytaj-dalej/wolnosc-rownoscaborcja/2016/ (accessed 15.04.2019). 
Suchecka, Justyna. 2018. "Dziś »czarny piątek«. Kobiety wychodzą na ulice, by walczyć o swoje prawa." Wyborcza.pl March 23. Retrieved from:

http://wyborcza.pl/7,75398,23178103,dzis-czarny-piatek-kobiety-wychodza-na-uliceby-walczyc-o.html (accessed 15.04.2019).

Super Express. 2018. “Czarny Piątek. Nawet 55 tys. osób na demonstracji w Warszawie.” Super Express March 23. Retrieved from:

https://www.se.pl/wiadomosci/polityka/czarny-piatek-czy-kobiety-ponownieprzestrasza-pis-relacja-na-zywo-aa-xLVv-cu7N-5ax7.html (accessed 15.04.2019).

Susdorf, Marek. 2017. “Utnij głodówkę, zerwij kołnierz!” Codziennik Feministyczny March 22. Retrieved form:_http://codziennikfeministyczny.pl/utnij-glowke-zerwij-kolnierzczarny-piatek/ (accessed 15.04.2019).

Szulęcka, Beata and Marta Olesik. 2016. "Strajk kobiet trwa. Nie dla TTiP i CETA!” Krytyka Polityczna October 14. Retrieved from:_http:/ / krytykapolityczna.pl/kraj/strajk-kobiettrwa-nie-dla-ttip-i-ceta/2016/ (accessed 15.04.2019).

Szcześniak, Agata. 2018. "Nie jestem kaleka. Nie przejmuje się moimi niesprawnymi nogami, tylko cellulitem na tyłku." Oko.press May 13. Retrieved from: https://oko.press/niejestem-kaleka-nie-przejmuje-sie-moimi-niesprawnymi-nogami-tylko-celulitem-na-tylku/ (accessed 15.04.2019).

Szcześniak, Agata. 2018. "Sanatorium pod Kuchcińskim. Kancelaria Sejmu przechwala się, jaką troską otoczyła protestujących niepełnosprawnych.” Oko.press June 1. Retrieved from: https://oko.press/kancelaria-sejmu-chwali-sie-pomoca-dla-protestujacymniepelnosprawnym-dbalismy-o-zdrowie-karmilismy-wypuszczalismy-dogosci/?fb_comment_id=1769018643156090_1772981332759821 (accessed 15.04.2019).

TVN24.pl. 2017. "Czarny Protest. Pierwsza z dziesięciu nauczycielek bez kary za Czarny Protest.” TVN 24 February 10. Retrieved form:_https://www.tvn24.pl/wiadomosci-zkraju,3/nauczycielki-poparly-czarny-protest-stana-przed-komisjadyscyplinarna,714399.html (accessed 15.04.2019).

TVN24.pl. 2017. "Panie robią hałas i pokazują kartki. Międzynarodowy Strajk Kobiet w stolicy." TVN 24 March 8. Retrieved from: https://tvnwarszawa.tvn24.pl/informacje,news,panie-robia-halas-i-pokazuja-kartkibrmiedzynarodowy-strajk-kobiet-w-stolicy,225925.html (accessed 15.04.2019).

TVN Warszawa. 2017. “Czarne parasolki wróciły na plac Zamkowy. »Wściekłe Polki«.” TVN Warszawa March 10. Retrieved from:

https://tvnwarszawa.tvn24.pl/informacje,news,czarne-parasolki-wrocily-na-placzamkowy-wsciekle-polki,242700.html (accessed 15.04.2019).

TVN24.pl. 2018. “»Zostajemy w Sejmie do skutku«. Protest rodziców dzieci niepełnosprawnych." TVN 24 April 18. Retrieved from: https://www.tvn24.pl/wiadomosci-z-kraju,3/sejm-protest-rodzicow-dzieciniepelnosprawnych-i-list-do-prezesa-pis,830548.html (accessed 15.04.2019). 
Wardziński Daniel. 2016. “Ogólnopolski strajk kobiet 3.10.2016 - mężczyźni też wspieraja pomysł protestu?”. Eska Rock October 3. Retreived from:

http://www.eskarock.pl/eska_rock_news/ogolnopolski_strajk_kobiet_3_10_2016__mezczyzni_tez_wspieraja_pomysl_protestu/134435 (accessed 15.04.2019).

Wieczorkiewicz, Patrycja. 2018. “»Czarny piątek«. »Politycy zapamiętaja go na długo«. Protesty nie tylko pod Sejmem." Wyborcza.pl March 21. Retrieved from: http://warszawa.wyborcza.pl/warszawa/7,54420,23172402,czarny-piatek-politycyzapamietaja-go-na-dlugo-protesty.html (accessed 15.04.2019).

Wieczorkiewicz, Patrycja. 2018. “Dlaczego idę na »Czarny piątek«.” Wyborcza.pl March 22. Retrieved from: http://warszawa.wyborcza.pl/warszawa/7,54420,23172978,dlaczegoide-na-czarny-piatek-komentarz-wieczorkiewicz.html (accessed 15.04.2019).

Wieczorkiewicz, Patrycja. 2018. "Strajk Kobiet wspiera strajk opiekunów osób niepełnosprawnościa." Wyborcza.pl Warszawa April 23.Retrieved from: http://warszawa.wyborcza.pl/warszawa/7,54420,23308866,strajk-kobiet-wspierastrajk-opiekunow-osob-z-niepelnosprawnoscia.html (accessed 15.04.2019).

Wielowieyska, Dominika. 2018. “Iwona Hartwich: »Na poprzednich protestach min. Rafalska stała obok nas i szeptała, by głosowac na PiS, bo oni nam pomogą. Dałam się oszukać»". Wyborcza.pl May 31. Retrieved from: http://wyborcza.pl/10,82983,23479769,iwona-hartwich-na-poprzednich-protestachmin-rafalska-stala.html (accessed 15.04.2019).

Wiśniewska, Agnieszka. 2016. "Polska wypowiedziała wojnę kobietom.” Krytyka Polityczna October 4. Retrieved from: http://krytykapolityczna.pl/felietony/agnieszkawisniewska/polska-wypowiedziala-wojne-kobietom/2016/ (accessed 15.04.2019).

Wróblewska, Dominika. 2016. "Jesteśmy dużo silniejsze, niż kiedykolwiek myślałyśmy." Krytyka Polityczna October 6. Retrieved from: http://krytykapolityczna.pl/kraj/miasto/jestesmy-duzo-silniejsze-niz-kiedykolwiekmyslalysmy/2016/ (accessed 15.04.2019).

Wyborcza.pl. 2018. "Iwona Hartwich: Przez te słowa premiera Morawieckiego boję się o swoja rodzinę." Wyborcza.pl June 1. Retrieved from: http://wyborcza.pl/10,152484,23482967,iwona-hartwich-przez-te-slowa-premieramorawieckiego-boje-sie.html (accessed 15.04.2019).

Piorun, Monika. 2018. "Strajk niepełnosprawnych w Sejmie. Ich opiekunowie upominają się o zasiłki." Radio Zet April 19. Retrieved from: https://zdrowie.radiozet.pl/Medycyna/Wiadomosci/Strajk-niepelnosprawnychOpiekunowie-walcza-w-Sejmie-o-zasilki (accessed 15.04.2019). 
Julia Kubisa - is an Assistant professor in the Institute of Sociology at the University of Warsaw. Her scientific interests include the gendered division of labour, industrial relations and sociology of work.

Katarzyna Rakowska - is a PhD candidate in the Institute of Sociology at University of Warsaw. She is working on a dissertation about the right to strike in Poland.

\section{ADDRESS:}

Instytut Socjologii Uniwersytetu Warszawskiego

Zakład Socjologii Pracy i Organizacji

Karowa 18

00-324 Warszawa

\section{EMAIL:}

kubisaj@is.uw.edu.pl

k.rakowska@is.uw.edu.pl

Citation: Kubisa, Julia and Katarzyna Rakowska. 2018. "Was it a strike? Notes on the Polish Women's Strike and the Strike of Parents of Persons with Disabilities." Praktyka Teoretyczna 4(30): 15-50.

DOI: $10.14746 /$ prt.2018.4.1

Autor: Julia Kubisa, Katarzyna Rakowska

TYTUŁ: Czy to był strajk? Refleksje na temat strajku polskich kobiet i strajku rodziców osób niepełnosprawnych

ABSTRAKT: Dwa znaczące protesty społeczne, które miały miejsce w Polsce w ostatnich latach - masowa mobilizacja kobiet przeciwko zakazowi aborcji i okupacja budynku Sejmu przez opiekunów osób niepełnosprawnych - nazywano strajkami. W artykule analizujemy wydarzenia związane ze Strajkiem Kobiet w 2016, 2017 i 2018 roku oraz strajk Rodziców Osób Niepełnosprawnych z 2018 roku, ujmując strajk jako formę protestu. Dlaczego obydwa protesty nazwano strajkami i jakie są implikacje określania ich przy użyciu terminologii z zakresu sporów zbiorowych? W Polsce strajki są formą zbiorowego, zinstytucjonalizowanego konfliktu pracowników najemnych, organizowanego wyłącznie przez związek zawodowy zarejestrowany w określonym miejscu pracy, a ich przedmiotem mogą być wyłącznie sprawy związane z miejscem pracy, nie zaś sprawy polityczne i znajdujące się poza gestia pracodawcy. Strajk Kobiet i protest Rodziców Osób Niepełnosprawnych nie były strajkami de iure, odrzucały 
jednak podział na produkcję (pracę najemna) i reprodukcję (praca nieodpłatna), co nadało szczególne znaczenie „odmowie pracy”, jaka miała wówczas miejsce. Użycie koncepcji strajku i stworzenie przestrzeni łączącej różne działania związane z walkami o prawa pracownicze i reprodukcyjne skutkowało upodmiotowieniem protestujących. Interpretujemy to jako strategię przejęcia typowych akcji protestacyjnych zarezerwowanych wcześniej dla pracowników najemnych.

SŁOWA KLUCzowe: strajk, protest, Strajk Kobiet, Czarny Protest, Rodzice Osób Niepełnosprawnych, praca reprodukcyjna, praca opiekuńcza 